\title{
APAKAH KINERJA JANGKA PANJANG PENAWARAN UMUM PERDANA DI INDONESIA UNDERPERFORMED?
}

\author{
Suherman ${ }^{1}$ \\ Fakultas Ekonomi Universitas Negeri Jakarta \\ Email: suherman@feunj.ac.id
}

\begin{abstract}
The objective of this research is to investigate the long-run performance of Indonesian Initial Public Offerings (IPOs). Sample of this research covers 101 IPO firms between 1999 and 2005 listed on Jakarta Stock Exchange. Sample is categorized into panel A (all IPOs sample), panel B (non-financial firm IPOs), panel C (non-privatized IPOs) and panel D (privatized IPOs). The results show that insignificant underperformance is found for EWCAR and VWCAR (except privatized IPOs showing insignificant outperformance), significant underperformance is found for EWBHAR (except privatized IPOs showing outperformance, although insignificant), and significant outperformance is found for VWBHAR (except privatized IPOs showing insignificant outperformance). The underperformance disappears, however, when calendar-time approach is utilized. The intercepts in Fama-French three-factor regressions are insignificantly different from zero, suggesting no abnormal performance.
\end{abstract}

Keywords: Long-run performance, value-weighted, equal-weighted

Abstrak: Tujuan dari penelitian ini adalah untuk mengetahui kinerja jangka panjang dari Penawaran Umum Perdana Indonesia (IPO). Sampel penelitian ini meliputi 101 perusahaan IPO antara tahun 1999 dan 2005 yang go public di Bursa Efek Jakarta. Sampel dikategorikan kedalam panel A (semua IPO), panel B (sampel perusahaan IPO nonkeuangan), panel $\mathrm{C}$ (sampel perusahaan IPO non-privatisasi) dan panel D (sampel perusahaan IPO privatisasi). Hasil penelitian menunjukkan bahwa kinerja jangka panjang mengalami underperformance yang tidak signifikan ketika diukur dengan EWCAR dan VWCAR (kecuali IPO privatisasi menunjukkan outperformance tidak signifikan), kinerja mengalami underperformance yang signifikan ketika diukur dengan EWBHAR (kecuali IPO privatisasi menunjukkan outperformance tidak signifikan), dan outperformance signifikan ditemukan ketika kinerja diukur dengan VWBHAR (kecuali IPO privatisasi menunjukkan outperformance yang tidak signifikan). Underperformance menghilang ketika pendekatan calendar-time digunakan untuk mengukur kinerja. Namun demikian, intersep model Fama-French three factors menunjukkan tidak signifikan yang berarti bahwa kinerja mengalami outperformance yang tidak signifikan.

Kata kunci: Kinerja jangka panjang, value-weighted, equal-weighted

\footnotetext{
${ }^{1}$ Penulis mengucapkan terima kasih pada Jay Ritter (University of Florida) atas diskusinya di Singapura (tahun 2007), di Oxford (2008), dan di Jakarta (2010). Penulis juga menyampaikan terima kasih kepada peserta 12th FMA (Financial Management Association) European Doctoral Student Seminar tahun 2008 di Praha, Republik Ceko atas saran dan diskusinya. Paper ini merupakan bagian dari disertasi penulis.
}

Jurnal Ekonomi/Volume XXI, N. 01, Maret 2016: 1-22 


\section{PENDAHULUAN}

Banyak studi mengungkapkan terjadinya underperformance setelah IPO. Fenomena tersebut terjadi di banyak negara, baik di pasar modal yang sudah maju maupun sedang berkembang, termasuk di Indonesia. Tabel 1 memberikan gambaran kinerja pasca IPOs baik underperformance maupun overperformance di beberapa negara. Diketahui bahwa underperformance tertinggi terjadi di Taiwan sebesar 55,12\%, dan underperformance terendah terjadi di Singapura sebesar 2,7\%. Sedangkan di BEJ, semua mengalami underperformance dimana berkisar antara 9,8\% sampai dengan 47,2\%. Outperformance tertinggi terjadi di Malaysia sebesar hampir 42\%. Uniknya, semua penelitian di Malaysia menunjukkan outperformance. Pasar modal di Swedia mengalami outperformance terendah yaitu $1,2 \%$.

Tabel 1. Kinerja Jangka Panjang Pasca IPO

\begin{tabular}{|c|c|c|c|c|}
\hline Negara & Peneliti & $\begin{array}{c}\text { Jumlah } \\
\text { IPO }\end{array}$ & Periode & $\begin{array}{c}\text { Kinerja } \\
\text { Pasca IPO }\end{array}$ \\
\hline Australia & Lee, Taylor, Walter (1996) & 266 & 1976-89 & $-46,5 \%$ \\
\hline Austria & Aussenegg (1997) & 57 & $1965-93$ & $-27,3 \%$ \\
\hline Brazil & Aggarwal, Leal, \& Hernandez (1993) & 62 & $1980-90$ & $-47,0 \%$ \\
\hline Canada & Kooli dan Suret (2003) & 445 & $1991-98$ & $-16,86 \%$ \\
\hline Chile & Aggarwal, Leal, \& Hernandez (1993) & 28 & $1982-90$ & $-23,7 \%$ \\
\hline Eropa (4 negara) & Vismara, Paleari, Ritter (2012) & 3755 & 1995-09 & $-19,0 \%$ \\
\hline Finland & Keloharju (1993) & 79 & 1984-89 & $-21,1 \%$ \\
\hline Germany & Ljungqvist (1997) & 145 & $1970-90$ & $-12,1 \%$ \\
\hline Hong Kong & Dawson (1987) & 21 & $1978-83$ & $-9,3 \%$ \\
\hline Indonesia & Pujiharjanto (2003) & 124 & $1992-98$ & $-9,78 \%$ \\
\hline Indonesia & Martani (2004) & 297 & $1989-00$ & $-35,37 \%$ \\
\hline Indonesia & Suroso (2005) & 216 & 1992-02 & $-18,95 \%$ \\
\hline Indonesia & Manurung dan Soepriyono (2006) & 71 & $2000-02$ & $-47,42 \%$ \\
\hline Indonesia & Suherman dan Buchdadi (2011) & 37 & $2001-05$ & $-25,68 \%$ \\
\hline Japan & Cai dan Wei (1997) & 172 & $1971-90$ & $-27,0 \%$ \\
\hline Korea & Kim, Krinsky, Lee (1995) & 99 & $1985-88$ & $+2,0 \%$ \\
\hline Malaysia & Dawson (1987) & 21 & $1978-83$ & $+18,2 \%$ \\
\hline Malaysia & Jelic, et.al (2001) & 182 & $1980-95$ & $+24,83 \%$ \\
\hline Malaysia & Corhay, et.al (2002) & 258 & $1992-96$ & $+41,71 \%$ \\
\hline Malaysia & $\begin{array}{l}\text { Ahmad-Zaluki, Campbell, Goodacre } \\
\text { (2007) }\end{array}$ & 454 & 1990-00 & $+32,63 \%$ \\
\hline Mexico & Aggarwal, Leal, \& Hernandez (1993) & 37 & $1987-90$ & $-19,6 \%$ \\
\hline New Zealand & Firth (1997) & 143 & $1979-87$ & $-10,0 \%$ \\
\hline Singapore & Dawson (1987) & 39 & $1978-83$ & $-2,7 \%$ \\
\hline Sweden & Loughran, Ritter, Rydqvist (1994) & 162 & $1980-90$ & $+1,2 \%$ \\
\hline Taiwan & Wen \& Cao (2013) & 121 & $2005-07$ & $-55,12 \%$ \\
\hline United Kingdom & Levis (1993) & 712 & $1980-88$ & $-8,1 \%$ \\
\hline USA & Loughran, Ritter (1995) & 4753 & $1970-90$ & $-20,0 \%$ \\
\hline USA & Eckbo, Norli (2000) & 6379 & $1972-98$ & $-28,8 \%$ \\
\hline USA & Gompers, Lerner (2003) & 3661 & $1935-72$ & $-21,3 \%$ \\
\hline USA & Ang, Gu, Hochberg (2005) & 4843 & $1970-96$ & $-20,2 \%$ \\
\hline
\end{tabular}

Tabel di atas diolah dari berbagai sumber.

Penelitian terkini oleh Peter (2015) menunjukkan bahwa kinerja jangka panjang IPO mengalami underperformed. Vismara et al (2012) menemukan kinerja jangka panjang IPO 
di pasar kedua mengalami underperformed. Wen dan Cao (2013) dan Ritter (1991) mengemukakan bahwa kinerja jangka panjang IPOs yang underperformed disebabkan oleh para investor yang sangat optimis dan ini menyebabkan harga saham naik. Dalam jangka panjang harga saham tersebut akan mengkoreksi kesalahannya sehingga return menjadi lebih rendah. Akan tetapi, Barber dan Lyon (1997), Brav dan Gompers (1997), Kothari dan Warner (1997), Fama (1998), Lyon et al. (1999), Brav et al. (2000), Loughran dan Ritter (2000), Eckbo et al. (2000), Mitchell dan Stafford (2000), Gompers dan Lerner (2003), Ahmad-Zaluki et al. (2007) mengungkapkan bahwa kinerja jangka panjang IPOs tergantung pada metode pengukuran yang dipakai dan besar kecilnya abnormal return serta keandalan kesimpulan statistik adalah berbeda antara satu metode dengan metode lainnya. Mereka mengutarakan bahwa penurunan kinerja bukanlah efek yang pasti terjadi setelah penawaran perdana saham dan kebanyakan anomali return jangka panjang cenderung akan hilang ketika teknik penelitian yang digunakan berbeda-beda.

Di Indonesia, penelitian kinerja jangka panjang IPOs memperlihatkan bahwa kinerja jangka panjang IPOs mengalami underperformance (diantaranya adalah Manurung dan Soepriyono, 2006; Suroso, 2005; Martani, 2004; Hartanto dan Ediningsih, 2004; dan Pujiharjanto, 2003). Sepengetahuan peneliti bahwa hamper semua penelitian tentang kinerja jangka panjang IPOs di Indonesia hanya menggunakan event-time approaches, yaitu cumulative abnormal returns (CARs) dan buy-and-hold abnormal returns (BHARs); uji signifikansi CARs dan BHARs hanya menggunakan t-statistik konvensional; benchmark kinerja yang dipakai hanya benchmark pasar yaitu IHSG; dan returns yang digunakan adalah equally-weighted.

Untuk itu, pada penelitian ini peneliti tidak hanya menggunakan event-time approach, tapi juga calendar-time approach (Fama-French Three Factor Model FFTFM). Mitchell dan Stafford (2000) mengatakan bahwa penggunaan event-time approach (CAR dan BHAR) menghasilkan signifikansi yang berlebihan pada abnormal return yang disebabkan adanya ketergantungan observasi. Fama (1998) menyarankan untuk membentuk portofolio bulanan berdasarkan waktu kalender (calendar-time approach) untuk menghitung kinerja jangka panjang. FFTFM digunakan untuk mengontrol kluster peristiwa (event clustering) dan korelasi antar returns IPO. Penelitian ini juga menggunakan returns yang dibobot secara equally dan value. Metode penghitungan equal-weighted returns mengasumsikan bahwa investor mengalokasikan dananya sama besar untuk setiap sekuritas dalam portofolio. Namun nyatanya, investor mengalokasikan uangnya tidak sama besar pada setiap aset di portofolio mereka. Lebih jauh penelitian ini juga menggunakan t-statistik konvensional dan bootstrapped-skewnessadjusted t-statistics ketika menguji signifikansi BHARs. Menurut Lyon et al. (1999), dalam Ahmad-Zaluki et al. (2007), metode bootstrapped-skewness-adjusted t-statistics menghasilkan 'uji statistik yang baik dalam menjelaskan sampel random, dan dalam kombinasi dengan portfolio yang dibentuk secara hati-hati, mengontrol dengan baik perusahaan sampel new listing, rebalancing, dan bias skewness'.

Hasil penelitian ini menunjukkan bahwa kinerja jangka panjang IPO tergantung pada metode pengukuran yang digunakan, yaitu 1)tidak signifikan underperformed ketika pengukuran menggunakan metode EWCAR dan VWCAR (kecuali IPO privatisasi outperformed tidak signifikan), 2)underperformed signifikan ketika menggunakan EWBHAR (kecuali IPO privatisasi outperformed tidak signifikan), 3)signifikan outperformed ketika pengukuran menggunakan VWBHAR (kecuali IPO privatisasi 
outperformed tidak signifikan), dan 4)tidak signifikan outperformed ketika diukur dengan model Fama-French Three Factor.

Berikut pada bagian 2 penelitian ini diuraikan kajian literatur terkait tema penelitian ini, kemudian bagian 3 menjelaskan metodologi penelitian ini, lalu pada bagian 4 diuraikan hasil penelitian ini, dan terakhir pada bagian 5 merupakan kesimpulan dan saran untuk penelitian berikutnya.

\section{KAJIAN TEORI}

Salah satu fenomena IPOs yang banyak diteliti adalah kinerja jangka panjang. Banyak hasil penelitian terdahulu menunjukkan bahwa kinerja jangka panjang IPO mengalami underperformance, baik di pasar modal maju maupun di pasar modal berkembang. Peter (2015), Wen dan Cao (2013), Manurung dan Soepriyono (2006), Suroso (2005), Martani (2004), Hartanto dan Ediningsih (2004), dan Pujiharjanto (2003) menemukan bahwa kinerja jangka panjang IPO mengalami underperformance. Mereka mendukung argumen yang dikemukakan Ritter (1991) bahwa kebanyakan investor terlalu optimis terhadap saham IPO sehingga menyebabkan harga saham naik. Beberapa waktu kemudian harga saham akan menyesuaikan ke nilai sebenarnya. Ini menyebabkan kinerja saham IPO tersebut mengalami underperformance dalam jangka panjang.

Peter (2015) menginvestigasi kinerja jangka pendek dan panjang 30 perusahaan IPO di Sri Lanka antara tahun 1996 sampai dengan 2000. Hasilnya menunjukkan bahwa kinerja IPO setelah satu, dan dua tahun mengalami outperformance sebesar $21,35 \%$ dan $30,92 \%$ tidak signifikan. Akan tetapi kinerja IPO setelah tiga tahun mengalami underperformance sebesar 12,96 tidak signifikan.

Wen dan Cao (2013) meneliti kinerja jangka panjang IPO di pasar modal Taiwan. Jumlah sampel 121 perusahaan IPO periode tahun 2005-2007 yang tercatat di Taiwan Stock Exchange (TSE) dan pasar OTC (GRETAI) . Mereka menemukan kinerja jangka panjang IPO setelah 1, 3 dan 5 tahun underperformed sebesar 6,3\%, 34,04\%, dan 55,12\%. Metode pengukuran yang digunakan adalah BHARs.

Vismara et al (2012) meneliti 3755 perusahaan IPOs yang tercatat di Prancis, Jerman, Italia dan UK. Sampel dikategorikan ke pasar utama dan pasar kedua. Hasilnya menunjukkan bahwa kinerja jangka panjang IPO setelah 3 tahun go public memperlihatkan kinerja yang berbeda antara IPO di pasar utama dan pasar kedua. Ratarata kinerja jangka panjang IPO di pasar utama di empat negara tersebut mengalami outperform sebesar $12,3 \%$, tapi sebaliknya rata-rata kinerja jangka panjang IPO di pasar kedua mengalami underperform sebesar 19,0\%.

Menggunakan sampel sebanyak 1526 perusahaan Amerika Serikat yang melakukan penawaran umum perdana antara tahun 1975 dan 1984, Ritter (1991) menemukan bahwa return rata-rata selama tiga tahun setelah IPO secara signifikan lebih rendah dibanding return rata-rata pasar. Dengan menggunakan metode pengukuran CAR, ditemukan bahwa kinerja satu, dua dan tiga tahun berturut-turut setelah IPO underperformed sebesar $10,23 \%, 16,89 \%$, dan $29,13 \%$.

Loughran (1993) mengungkapkan terjadinya underperformance selama enam tahun setelah IPO yaitu sebesar 17,29\% dibandingkan return pasar yang sebesar 76,23\%. Penelitiannya menggunakan sampel 3556 yang tercatat di NASDAQ dalam periode 19671987. Servaes dan Rajan (1997) meneliti IPO dari tahun 1975-1987. Mereka menemukan 
kinerja perusahaan setelah IPO selama 5 tahun hanya 24\%, sedangkan return pasar (NYSE index) mencapai $71 \%$.

Loughran dan Ritter (1995) memperluas temuan Ritter (1991). Loughran dan Ritter (1995) meneliti IPO tahun 1970-1990 dengan sampel 4753 perusahaan dan menemukan terjadinya underperformance. Mereka mengatakan bahwa setelah IPO return rata-rata sebesar $5 \%$ pertahun selama 5 tahun, sedangkan return pasar $12 \%$ setiap tahun selama lima tahun. Levis (1993) meneliti 712 perusahaan yang melakukan IPO di United Kingdom selama 1980-1988. Ia menemukan underperformance sebesar antara 8,3\%-23\%, tergantung patok duga yang dipilih.

Underperformance tidak hanya terjadi di pasar-pasar modal yang maju tetapi juga terjadi di pasar-pasar modal berkembang. Aggarwal et al. (1993) menemukan bahwa kinerja perusahaan IPO di Brazil mengalami underperformance sebesar $47 \%$ setelah tiga tahun. Sedangkan di Chile, underperformance setelah tiga tahun rata-rata sebesar 23,7\%, dan di Mexico underperformance rata-rata sebesar 19,6\% setahun setelah IPO. Dawson (1987) meneliti kinerja IPO di Hong Kong dan Singapura. Ia menemukan underperformance yang tidak signifikan di Hong Kong sebesar 9,3\%, dan di Singapura $2,7 \%$ setelah satu tahun IPO. Sampel penelitiannya adalah sampel yang melakukan IPO antara tahun 1978-1984.

Suherman dan Buchdadi (2011) mengemukakan bahwa umumnya perusahaan nonshariah mengalami kinerja yang underperformed setelah satu dan dua tahun pasca IPO baik ketika diukur dengan CARs maupun BHARs. Ketika diukur dengan EWBHARs, kinerja mengalami underperformance sebesar $25,68 \%$ dan $75,63 \%$ setelah satu dan dua tahun IPO. Lebih jauh, pengukuran kinerja dengan metode EWCARs menunjukkan bahwa kinerja IPO mengalami underperformed sebesar $13,51 \%$ satu tahun setelah IPO, tetapi kinerja mengalami outperformance sebesar 4,82\% setelah dua tahun IPO. Sampel penelitiannya adalah 37 non shari'ah-based firms dan melakukan IPO pada periode Juli 2001 sampai dengan Desember 2005.

Manurung dan Soepriyono (2006) meneliti kinerja jangka panjang IPO di Indonesia dengan periode 2000-2002 dengan sampel 71 perusahaan. Dengan menggunakan perhitungan EWBHAR, mereka mengungkapkan bahwa performa emiten non privatisasi setelah satu, dua, dan tiga tahun IPO mengalami underperformance sebesar 8,27\%, $26,60 \%$, dan $47,42 \%$. Return pasar yang digunakan sebagai benchmark ialah return IHSG.

Suroso (2005) mengungkapkan bahwa kinerja perusahaan satu tahun pasca IPO yang diukur dengan EWBHAR adalah underperformed sebesar 18,95\% untuk seluruh perusahaan yang melakukan IPO tahun 1992-2002 yang berjumlah 216. Untuk sampel manufaktur, perusahaan yang melakukan IPO tahun 1992-1996 mengalami underperformance sebesar 13,81\% setelah satu tahun, tahun 1997-1999 underperformed $14,95 \%$, dan tahun 2000-2002 underperformed sebesar 24,28\%. Jadi, rata-rata underperformance ketiga periode tersebut adalah $17,68 \%$. Return pasar yang digunakan sebagai benchmark ialah return IHSG.

Martani (2004) mengukur kinerja jangka panjang dengan periode pengamatan 250 hari, 500 hari, 750 hari, 1000 hari, dan 1250 hari pasca IPO. Hasilnya menunjukkan bahwa umumnya kinerja jangka panjang mengalami underperformance. Dengan metode EWBHARs, kinerja jangka panjang pada periode pengamatan di atas adalah -0,07\%; 9,15\%; -17,58\%; -32,77\%; dan -35,37\%. Sedangkan dengan pengukuran EWCARs adalah $1,9 \% ;-1,66 \% ;-11,05 \% ;-22,86 \%$; dan $-19,93 \%$. Return pasar yang digunakan sebagai 
benchmark ialah return IHSG. Sampel penelitian ini adalah 297 perusahaan yang melakukan IPO tahun 1989 - 2000.

Hartanto dan Ediningsih (2004) menemukan bahwa setelah satu tahun melakukan IPO, kinerja perusahaan underperformed sebesar 7,83\% untuk periode 1992-2001. Selama periode sebelum krisis moneter, 1992-Juni 1996, kinerja perusahaan underperformed sebesar 10,00\%. Sedangkan periode Juli 1997-2001 kinerja perusahaan juga underperformed sebesar 5,79\%. Returns dihitung secara equally-weighted. Return pasar yang digunakan sebagai benchmark ialah return IHSG.

Pujiharjanto (2003), yang juga menggunakan metode perhitungan EWCARs, mengatakan bahwa kinerja perusahaan setelah dua belas bulan IPO mengalami underperformance sebesar 9,78\% di BEJ. Return pasar yang digunakan sebagai benchmark ialah return IHSG. Periode penelitiannya tahun 1992-1998. Sampel sebanyak 124 perusahaan manufaktur.

Berlainan dengan hasil penelitian di atas, penelitian-penelitian di banyak negara menunjukkan bahwa kinerja jangka panjang IPO tergantung pada metode pengukuran yang digunakan. Kinerja jangka panjang IPO tergantung pada metode dan alat statistik yang digunakan dalam mengukur kinerja IPOs. Ahmad-Zaluki et al. (2007) menginvestigasi kinerja harga saham jangka panjang pada 454 perusahaan IPO Malaysia yang tercatat di KLSE selama periode tahun 1990-2000. Hasilnya adalah IPO Malaysia secara signifikan outperform dibanding return pasar ketika kinerja diukur dengan menggunakan EWCARs dan EWBHARs. Namun demikian, overperformance yang signifikan tersebut hilang ketika returns dihitung berdasarkan pada VWCARs, VWBHARs dan diregresikan kedalam model Fama-French (1993). Jelic et al. (2001), dan Corhay et al. (2002) juga menyatakan outperformance terjadi di pasar modal Malaysia sebesar $24,83 \%$, dan $41,71 \%$.

Ang et al. (2005) meneliti kinerja selama lima tahun setelah IPO dengan jumlah sampel 4843 perusahaan yang melakukan penawaran perdana pada periode 1970 sampai 1996 di NYSE, AMEX, dan NASDAQ. Mereka mengatakan bahwa underperformance dan outperformance terjadi tergantung pada metode pengukuran dan benchmark yang digunakan. Perhitungan return pasca IPO menggunakan event-time dan calendar time approaches. Benchmarks yang digunakan adalah value-weighted NYSE dan AMEX index, value-weighted NASDAQ index, dan smallest decile NYSE.

Gompers dan Lerner (2003) meneliti 3661 perusahaan IPO dari 1935 sampai 1972 untuk periode pengamatan lima tahun setelah IPO. Temuan-temuan mereka memberitahukan bahwa kinerja IPO tergantung pada metode yang dipakai untuk mengukur returns. Hasil-nya menunjukkan underperformance terjadi ketika return diukur dengan VWBHARs. Tetapi, underperformance hilang ketika EWBHARs. Return IPO menjadi sama dengan pasar ketika menggunakan calendar-time analysis (FFTFM).

Espenlaub et al. (2000) memberikan bukti kinerja jangka panjang sehubungan dengan metode yang dipakai. Menggunakan data 588 perusahaan IPO di Inggris selama periode 1985 sampai 1992, mereka membandingkan return abnormal berdasarkan pada lima benchmarks yang memakai event-time approach dan calender-time approach. Selama lima tahun setelah IPO, underperformance tergantung pada benchmarks yang dipakai yaitu ketika return diukur dengan pendekatan event-time tingkat underperformance tinggi, dan ketika return diukur dengan calender-time approach tingkat underperformance rendah. 


\section{METODE}

Sampel. Populasi penelitian ini adalah perusahaan yang tercatat di Bursa Efek Jakarta. Sampel diambil berdasarkan kriteria bahwa perusahaan melakukan IPO saham biasa (unit offerings maupun non unit offerings), dan periode IPO tahun 1999-2005. IPO saham biasa yang terjadi antara tahun 1999-2005 adalah 101 perusahaan.

Data. Data yang dipergunakan untuk keperluan penelitian ini adalah data sekunder. Kinerja jangka panjang membutuhkan data return bulanan berdasarkan tanggal IPO perusahaan, bukan setiap akhir bulan. Misal; PT. Mitra Adiperkasa (MAPI) go public tanggal 10 November 2004. Maka menghitung return bulanan-nya diambil dari harga saham tanggal 10 November 2004, 10 Desember 2004, dan seterusnya. Harga saham bulanan didapatkan di Pusat Data Pasar Modal (PDPM) Institut Bisnis dan Informatika Indonesia (IBII - Kwik Kian Gie Business School). Di samping data harga saham bulanan, diperlukan juga kapitalisasi pasar bulanan. Kapitalisasi pasar diperlukan ketika return dihitung berdasarkan value-weighted. Kapitalisasi pasar didapatkan dari perkalian harga saham dengan jumlah saham yang beredar. Data jumlah saham beredar dilihat di Indonesian Capital Market Directory (ICMD) di PDPM IBII.

Karena pengukuran kinerja jangka panjang diatas disesuaikan dengan return pasar, maka dibutuhkan harga pasar. Harga pasar pada penelitian ini menggunakan proksi nilai IHSG dan LQ45. Data IHSG dan LQ45 diambil dari PDPM IBII. Tanggal data IHSG disesuaikan dengan tanggal data harga saham perusahaan. Misal; jika PT. Mitra Adiperkasa (MAPI) memerlukan data harga saham tanggal 10 November 2004, 10 Desember 2004, dan seterusnya, maka data IHSG yang dipakai adalah 10 November 2004, 10 Desember 2004, dan seterusnya.

Data SBI (suku bunga Sertifikat Bank Indonesia) didapatkan dari PDPM Fakultas Ekonomi dan Bisnis UGM, kecuali tahun 2007 dari PDPM IBII. Tanggal data SBI disesuaikan dengan tanggal data harga saham perusahaan IPO. Misal; jika PT. Mitra Adiperkasa (MAPI) memerlukan data harga saham tanggal 10 November 2004, 10 Desember 2004, dan seterusnya, maka data SBI yang dipakai adalah 10 November 2004, 10 Desember 2004, dan seterusnya. SBI yang digunakan adalah SBI 30 hari. Suku bunga SBI dibagi 12 bulan untuk mendapatkan suku bunga bebas risiko bulanan.

Metode Analisis. Kinerja jangka panjang perusahaan pasca IPO dihitung berdasarkan event-time approach dan calendar-time approach. Yang termasuk event-time adalah cumulative abnormal returns dan buy-and-hold abnormal returns. Sedangkan yang termasuk calendar-time adalah Fama-French Three Factor Pricing Model.

Cumulative Abnormal Returns (CARs). CARs merupakan salah satu metode untuk menghitung kinerja jangka panjang sekuritas. Pertama, hitung return bulanan pasca IPO selama tiga tahun periode pengamatan. Return bulanan sekuritas i periode $t$ dihitung sebagai berikut:

$$
r_{i, t}=\left(P_{i, t}-P_{i, t-1}\right) / P_{i, t-1}
$$


dimana $P_{i, t}$ adalah harga sekuritas i periode bulan $t$, dan $P_{i, t-1}$ ialah harga sekuritas i periode bulan $t$ - 1 . Kemudian return bulanan sekuritas i yang disesuaikan return pasar dikalkulasi sebagai berikut:

$$
a r_{i, t}=r_{i, t}-r_{m, t}
$$

dimana $r_{i, t}$ adalah return perusahaan i pada periode bulan $t$, dan $r_{m, t}$ adalah return pasar pada periode bulan $t$. Return pasar menggunakan proksi IHSG dan LQ45. Lalu return abnormal rata-rata portofolio periode $t$ adalah:

$$
A R_{t}=\frac{1}{n} \sum_{i=1}^{n} a r_{i, t}
$$

Selanjutnya, CAR (yang telah disesuaikan) adalah total return rata-rata (yang telah disesuaikan) setiap bulan selama tiga tahun adalah :

$$
C A R_{t}=\sum_{s=1}^{t} A R_{s}
$$

Perhitungan CARs diatas mengasumsikan bahwa investor mengalokasikan dananya sama besar untuk setiap sekuritas dalam portofolio (equally-weighted). Nyatanya, banyak investor berinvestasi tidak sama besar pada setiap asset di suatu portofolio. Karena itu, selain menggunakan EWCARs diatas, juga digunakan VWCARs. Berikut ini perhitungan value-weighted abnormal return (VWAR):

$$
V W A R_{t}=\frac{\sum_{i=1}^{n} \operatorname{MKTCAP}_{i, t-1} x a r_{i, t}}{\sum_{i=1}^{n} \operatorname{MKTCAP}_{i, t-1}}
$$

VWARs dihitung dengan membobotkan setiap return yang telah disesuaikan dengan kapitalisasi pasar perusahaan $\left(M K T C A P_{i}\right)$ pada periode sebelumnya. Selanjutnya, VWCAR adalah:

$$
V W C A R_{t}=\sum_{s=1}^{t} V W A R_{s}
$$

Buy-and-Hold Abnormal Returns (BHARs). Penelitian ini juga menggunakan metode BHARs untuk mengukur kinerja jangka panjang. BHARs dipakai untuk mengurangi bias statistik dalam mengukur kinerja kumulatif jangka panjang pada metode CARs (Conrad dan Kaul, 1993). Market adjusted buy-and-hold return perusahaan i pada bulan $t$ dihitung sebagai berikut:

$$
\text { BHAR }_{i, t}=\prod_{t=1}^{T}\left(1+r_{i, t}\right)-\prod_{t=1}^{T}\left(1+r_{m, t}\right)
$$

dimana $r_{i, t}$ adalah return mentah bulanan perusahaan i pada bulan $\mathrm{t} ; r_{m, t}$ merupakan return pasar pada bulan t; dan $\mathrm{T}$ adalah bulan ke 12, 24, dan 36. Metode ini mengukur total 
return dari strategi buy-and-hold dimana saham dibeli pada harga penutupan di hari listing dan ditahan sampai tahun 1, 2, dan 3.

Setelah mendapatkan $B H A R_{i, t}$ kemudian menghitung mean buy-and-hold abnormal return untuk period t sebagai berikut:

$$
\overline{\text { BHAR }_{t}}=\sum_{i=1}^{n} \omega_{i} B H A R_{i, t}
$$

Ketika return dihitung secara tertimbang rata-rata (equally-weighted), $\omega_{i}=1 / n$, dan bila dihitung berdasarkan value-weighted, $\omega_{i}=M V_{i} / \sum_{i} M V_{i}$, dimana $M V_{i}$ adalah nilai kapitalisasi pasar saham perusahaan yang IPO pada hari pertama perdagangan.

Fama-French Three Factor Model (FFTFM). Mitchell dan Stafford (2000) mengatakan bahwa penggunaan metode CAR dan BHAR menghasilkan signifikansi yang berlebihan pada abnormal return yang disebabkan adanya ketergantungan observasi. Fama (1998) menyarankan untuk membentuk portofolio bulanan berdasarkan waktu kalender (calendar-time approach) untuk menghitung kinerja jangka panjang. FFTFM digunakan untuk mengontrol kluster peristiwa (event clustering) dan korelasi antar returns IPO. FFTFM telah banyak digunakan untuk mengukur kinerja IPO jangka panjang antara lain oleh Brav dan Gompers (1997), Espenlaub et al. (2000), Brav et al. (2000), Gompers dan Lerner (2003), Ang et al. (2005), dan Ahmad-Zaluki et al. (2007).

FFTFM adalah sebagai berikut:

$$
R_{p, t}-R_{r f, t}=a_{p}+\beta_{p}\left(R_{m, t}-R_{r f, t}\right)+s_{p} S M B_{t}+h_{p} H M L_{t}+e_{p, t}
$$

Variabel dependen adalah excess return portofolio (return portofolio periode $\mathrm{t}$ dikurangi return bebas risiko/Sertifikat Bank Indonesia periode t). Variabel independennya adalah excess market return, SMB (size), dan HML (book-to-market ratio). SBI yang digunakan adalah SBI 30 hari. Return pasar yang digunakan ialah return IHSG. SMB (Small Minus Big) adalah return portofolio perusahaan kecil (small firms) dikurangi return portofolio perusahaan besar (big firms). HML (High Minus Low) ialah return portofolio perusahaan dengan rasio book-to-market tinggi dikurangi return portofolio perusahaan dengan rasio book-to-market rendah. Perusahaan diurutkan berdasarkan ukuran (size) dan rasio book-tomarket. Kemudian berdasarkan ukuran, perusahaan dibagi menjadi dua kelompok. Perusahaan yang ukurannya lebih besar daripada rata-rata ukuran seluruh perusahaan dikategorikan perusahaan besar (B), sedangkan yang ukurannya lebih kecil dari rata-rata ukuran seluruh perusahaan dikategorikan perusahaan kecil (S). Perusahaan dengan rasio book-to-market diatas titik potong 70 persen (the 70 percent book-to-market breakpoint) diberi label $\mathrm{H}$ (high atau tinggi), 40 persen ditengah diberi label M (Medium), dan perusahaan dibawah titik potong 30 persen diberi label $\mathrm{L}$ (low atau rendah). Kemudian dibentuk enam portofolio yaitu berdasarkan S/L, S/M, S/H, B/L, B/M, dan B/H. $\mathrm{SMB}=[(\mathrm{S} / \mathrm{L}-\mathrm{B} / \mathrm{L})+(\mathrm{S} / \mathrm{M}-\mathrm{B} / \mathrm{M})+(\mathrm{S} / \mathrm{H}-\mathrm{B} / \mathrm{H})] / 3$, dan $\mathrm{HML}=[(\mathrm{S} / \mathrm{H}-\mathrm{S} / \mathrm{L})+(\mathrm{B} / \mathrm{H}-\mathrm{B} / \mathrm{L})] / 2$. Alpha $\left(\alpha_{p}\right)$ mengindikasikan abnormal return. Jika uji t menunjukkan $a_{p}$ signifikan (tidak signifikan), berarti overperformance atau underperformance signifikan (tidak signifikan).

Uji Hipotesis. Pengujian hipotesis dilakukan dengan beberapa cara tergantung metode pengukuran kinerja yang digunakan. Ketika menggunakan CARs, $t$ hitung dicari dengan memakai rumus yang digunakan oleh Ritter (1991), yaitu sebagai berikut: 


$$
t-\operatorname{hit}\left(C A R_{1, t}\right)=C A R_{1, t} * \sqrt{n_{t}} / \operatorname{csd}
$$

dimana $\mathrm{n}_{\mathrm{t}}$ ialah jumlah perusahaan di bulan $\mathrm{t}$, dan $\operatorname{csd}_{\mathrm{t}}$ dicari dengan rumus berikut:

$$
\operatorname{csd} d_{t}=[t * v a r+2 *(t-1) * \operatorname{cov}]^{0,5}
$$

dimana $\mathrm{t}$ adalah bulan ke $\mathrm{t}$, var ialah rata-rata varian selama periode pengamatan, dan cov yaitu auto-kovarians order pertama dari $\mathrm{AR}_{\mathrm{t}}$ (the first-order autocovariance of the $A R_{t}$ series). Setelah diketahui thitung, lalu tentukan $t$ tabel. Jika t hitung lebih besar daripada $t$ tabel, underperformance / outperformance signifikan terjadi. Sebaliknya, bila t hitung lebih kecil daripada $\mathrm{t}$ tabel, underperformance / outperformance tidak terjadi secara signifikan. Tingkat signifikansi adalah $1 \%, 5 \%$, dan $10 \%$.

Ketika BHARs dipakai untuk mengukur kinerja, maka $t$ hitung yang digunakan adalah $\mathrm{t}$ hitung konvensional dan $\mathrm{t}$ hitung yang disesuaikan dengan skewness (bootstrapped skewness-adjusted $t$-statistic) (Lyon et al., 1999) yaitu sebagai berikut:

$$
t-h i t=\sqrt{n}\left(S+\frac{1}{3} \hat{\gamma} S^{2}+\frac{1}{6 n} \hat{\gamma}\right)
$$

dimana;

$$
\begin{gathered}
S=\frac{\overline{\text { BHAR }_{t}}}{\sigma\left(\text { BHAR }_{t}\right)}, \\
\hat{\gamma}=\frac{\sum_{i=1}^{n}\left(B H A R_{i, t}-\overline{\text { BHAR }_{t}}\right)^{3}}{n \sigma\left(\text { BHAR }_{t}\right)^{3}}
\end{gathered}
$$

dimana $\hat{y}$ adalah estimasi koefisien skewness, $\mathrm{n}^{0.5} \mathrm{~S}$ merupakan $\mathrm{t}$ hitung konvensional. Setelah $\mathrm{t}$ hitung ditentukan, maka $\mathrm{t}$ tabel dicari. Bila $\mathrm{t}$ hitung lebih besar (kecil) daripada $\mathrm{t}$ tabel, maka underperformance / outperformance signifikan (tidak signifikan) terjadi. Tingkat signifikansi adalah $1 \%, 5 \%$, dan $10 \%$.

Terakhir, ketika kinerja jangka panjang IPO diukur dengan FFTFM, uji t-statistik yang digunakan adalah t-statistik konvensional. Nilai alpha $\left(\alpha_{p}\right)$ pada FFTFM mengindikasikan abnormal return. Jika uji t menunjukkan $a_{p}$ signifikan (tidak signifikan), berarti overperformance atau underperformance signifikan (tidak signifikan).

\section{DESKRIPTIF DAN PEMBAHASAN}

Tabel 2 dibawah ini adalah mengenai statistik deskriptif. Pada panel A (semua IPO), ratarata dana IPO adalah 185 milyar rupiah lebih. Dana IPO terendah adalah 7,8 milyar rupiah, dan tertinggi sebesar 4 trilyun 169 milyar rupiah lebih. Standar deviasi dana IPO sebesar 568,4 milyar rupiah. Rata-rata return awal IPO adalah 48,5\%. Return awal terendah dan tertinggi sebesar $-32,55 \%$ dan $480 \%$. Standar deviasi return awal sebesar 70,93\%. Pada panel B (IPO manufaktur), rata-rata dana IPO adalah 141, 9 milyar rupiah. Dana IPO terendah adalah 7,8 milyar rupiah, dan tertinggi sebesar 2 trilyun 855 milyar rupiah. Standar deviasi dana IPO sebesar 418,2 milyar rupiah. Rata-rata return awal IPO adalah 58,6\%. Return awal terendah dan tertinggi sebesar $-30,00 \%$ dan $480 \%$. Standar 
deviasi return awal sebesar 79,85\%. Pada panel C (IPO non-privatisasi), rata-rata dana IPO yang diperoleh adalah 107,5 milyar rupiah. Dana IPO terendah sebesar 7,8 milyar rupiah, dan tertinggi sebesar 2 milyar 855 juta rupiah. Rata-rata return awal hari pertama sebesar $51,41 \%$. Return awal terendah dan tertinggi adalah $-32,55 \%$ dan $480 \%$. Pada panel D (IPO privatisasi), rata-rata dana yang diperoleh dari IPO sebesar 1 trilyun 255 milyar rupiah lebih. Dana IPO terendah adalah 59 milyar 570 juta rupiah, dan tertinggi ialah 4 trilyun 169 milyar rupiah lebih. Rata-rata return awal hari pertama ialah 9,33\%. Return awal terendah sebesar $-8 \%$ dan tertinggi sebesar $25,92 \%$.

Tabel 2. Statistik Deskriptif IPO

\begin{tabular}{lccccc}
\hline & Rata-rata & $\begin{array}{l}\text { Standar } \\
\text { Deviasi }\end{array}$ & $\begin{array}{l}\text { Nilai } \\
\text { Min. }\end{array}$ & Median & $\begin{array}{c}\text { Nilai } \\
\text { Maks. }\end{array}$ \\
\hline $\begin{array}{l}\text { Panel A: Semua } \\
\text { IPO }(n=101)\end{array}$ & & & & & \\
$\begin{array}{l}\text { Dana dari IPO } \\
\text { (milyar Rp.) }\end{array}$ & 185,01 & 568,42 & 7,80 & 33,00 & $4.169,11$ \\
Return awal (\%) & 48,50 & 70,93 & $-32,55$ & 23,33 & 480,00 \\
$\begin{array}{l}\text { Panel B: } \\
\begin{array}{l}\text { IPO manufaktur } \\
\text { (n=70) }\end{array}\end{array}$ & & & & & \\
$\begin{array}{l}\text { Dana dari IPO } \\
\text { (milyar Rp.) }\end{array}$ & 141,93 & 418,20 & 7,80 & 30,20 & $2.855,00$ \\
Return awal (\%) & 58,60 & 79,85 & $-30,00$ & 27,01 & 480,00 \\
$\begin{array}{l}\text { Panel C: } \\
\begin{array}{l}\text { IPO Non Privatisasi } \\
\text { (n=94) }\end{array}\end{array}$ & & & & & \\
$\begin{array}{l}\text { Dana dari IPO } \\
\text { (milyar Rp.) }\end{array}$ & 107,52 & 321,47 & 7,80 & 29,51 & $2.855,00$ \\
Return awal (\%) & 51,41 & 72,64 & $-32,55$ & 25,59 & 480,00 \\
$\begin{array}{l}\text { Panel D: } \\
\begin{array}{l}\text { IPO Privatisasi } \\
\text { (n=7) }\end{array}\end{array}$ & & & & & \\
$\begin{array}{l}\text { Dana dari IPO } \\
\text { (milyar Rp.) }\end{array}$ & $1.225,58$ & $1.557,52$ & 59,57 & 199,23 & $4.169,11$ \\
Return awal (\%) & 9,33 & 11,94 & $-8,00$ & 5,00 & 25,92 \\
\hline
\end{tabular}

Return awal dihitung dengan rumus $\left(\left(\mathrm{P}_{\mathrm{t}}-\mathrm{P}_{0}\right) / \mathrm{P}_{0}\right)$ dimana $\mathrm{P}_{0}$ adalah harga jual saat IPO, dan $\mathrm{P}_{\mathrm{t}}$ ialah harga penutupan hari pertama perdagangan. Dana IPO ialah dana yang diperoleh dari penjualan saham IPO (harga penawaran per lembar dikali jumlah saham yang dijual ke publik). $n$ adalah jumlah perusahaan. Sumber: Data diolah.

Analisis Cumulative Abnormal Returns. Tabel 3 memperlihatkan kinerja jangka panjang yang diukur dengan menggunakan Cumulative Abnormal Returns (CARs). Analisis kinerja tersebut dikelompokkan ke dalam empat bagian yaitu 1)kinerja jangka panjang 
semua IPO (panel A), 2)kinerja jangka panjang IPO manufaktur (panel B), 3)kinerja jangka panjang IPO non privatisasi (panel C), dan 4)kinerja jangka panjang IPO privatisasi (panel D). Periode pengamatan kinerja jangka panjang IPO adalah 1, 2 dan 3 tahun setelah IPO. Seluruh hasil uji t-statistik memperlihatkan bahwa kinerja jangka panjang IPO tidak signifikan outperformed ataupun underperformed pada semua panel.

Tabel 3. Kinerja Jangka Panjang IPOs Diukur dengan Cumulative Abnormal Returns (CARs)

\begin{tabular}{|c|c|c|c|c|c|c|c|c|c|c|c|c|}
\hline & \multicolumn{12}{|c|}{ PANEL A: SEMUA IPO } \\
\hline & \multicolumn{6}{|c|}{ Disesuaikan IHSG } & \multicolumn{6}{|c|}{ Disesuaikan LQ45 } \\
\hline & \multicolumn{2}{|c|}{1 tahun } & \multicolumn{2}{|c|}{2 tahun } & \multicolumn{2}{|c|}{3 tahun } & \multicolumn{2}{|c|}{1 tahun } & \multicolumn{2}{|c|}{2 tahun } & \multicolumn{2}{|c|}{3 tahun } \\
\hline & EW & VW & EW & VW & EW & VW & EW & VW & EW & VW & EW & VW \\
\hline CAR $(\%)$ & $-10,40$ & $-9,05$ & $-8,74$ & $-7,90$ & $-10,72$ & $-6,73$ & $-20,91$ & $-10,53$ & $-22,15$ & $-9,80$ & $-24,96$ & $-9,21$ \\
\hline t-stat & $-0,64$ & $-0,60$ & $-0,37$ & $-0,37$ & $-0,36$ & $-0,24$ & $-1,19$ & $-0,64$ & $-0,89$ & $-0,42$ & $-0,78$ & $-0,31$ \\
\hline \multirow[t]{3}{*}{$\mathrm{N}$} & 101 & 101 & 101 & 101 & 93 & 93 & 101 & 101 & 101 & 101 & 93 & 93 \\
\hline & \multicolumn{2}{|c|}{1 tahun } & Disesuc & n IHSG & PAN & B: IPO & IANUF & TUR & Disesua & in LQ45 & & \\
\hline & $\mathrm{EW}^{1}$ & VW & $\mathrm{EW}^{2}$ & un & $\mathrm{EW}^{5}$ & VW & $\mathrm{EW}^{1}$ & VW & $\mathrm{EW}$ & $\begin{array}{l}\text { Un } \\
\text { VW }\end{array}$ & $\mathrm{EW}^{3}$ & VW \\
\hline CAR $(\%)$ & $-9,71$ & $-25,12$ & 0,56 & $-20,77$ & $-10,36$ & $-33,64$ & $-12,90$ & $-25,20$ & $-6,08$ & $-20,87$ & $-17,64$ & $-32,85$ \\
\hline t-stat & $-0,46$ & $-1,29$ & 0,01 & $-0,75$ & $-0,27$ & $-0,96$ & $-0,61$ & $-1,31$ & $-0,20$ & $-0,76$ & $-0,47$ & $-0,95$ \\
\hline \multirow[t]{3}{*}{$\mathrm{N}$} & 70 & 70 & 70 & 70 & 66 & 66 & 70 & 70 & 70 & 70 & 66 & 66 \\
\hline & \multicolumn{2}{|c|}{1 tahun } & \multicolumn{2}{|c|}{$\begin{array}{c}\text { Disesuaikan IHSG } \\
2 \text { tahun }\end{array}$} & \multicolumn{2}{|c|}{3 tahun } & N PRIY & TISASI & Disesua & in LQ45 & \multicolumn{2}{|c|}{3 tahun } \\
\hline & EW & VW & EW & VW & EW & VW & EW & VW & EW & VW & EW & VW \\
\hline CAR $(\%)$ & $-13,53$ & $-15,54$ & $-13,03$ & $-24,49$ & $-13,53$ & $-32,45$ & $-24,59$ & $-17,17$ & $-27,15$ & $-26,79$ & $-28,53$ & $-34,67$ \\
\hline t-stat & $-0,80$ & $-1,02$ & $-0,54$ & $-1,14$ & $-0,44$ & $-1,18$ & $-1,36$ & $-1,04$ & $-1,06$ & $-1,15$ & $-0,87$ & $-1,16$ \\
\hline \multirow[t]{5}{*}{$\mathrm{N}$} & 94 & 94 & 94 & 94 & 86 & 86 & 94 & 94 & 94 & 94 & 86 & 86 \\
\hline & \multicolumn{12}{|c|}{ PANEL D: IPO PRIVATISASI } \\
\hline & \multirow{2}{*}{\multicolumn{2}{|c|}{1 tahun }} & \multirow{2}{*}{\multicolumn{2}{|c|}{$\begin{array}{c}\text { Disesuaikan IHSG } \\
2 \text { tahun }\end{array}$}} & \multirow{2}{*}{\multicolumn{2}{|c|}{3 tahun }} & & & \multicolumn{2}{|c|}{ Disesuaikan LQ45 } & & \\
\hline & & & & & & & & & & & \multicolumn{2}{|c|}{3 tahun } \\
\hline & EW & VW & EW & VW & EW & VW & EW & VW & EW & VW & EW & VW \\
\hline CAR $(\%)$ & 31,54 & 15,48 & 48,89 & 34,00 & 28,60 & 49,78 & 28,54 & 15,87 & 44,95 & 34,83 & 24,55 & 49,51 \\
\hline t-stat & 1,65 & 0,93 & 1,80 & 1,45 & 0,86 & 1,74 & 1,55 & 0,93 & 1,72 & 1,45 & 0,76 & 1,68 \\
\hline $\mathrm{N}$ & 7 & 7 & 7 & 7 & 7 & 7 & 7 & 7 & 7 & 7 & 7 & 7 \\
\hline
\end{tabular}

Sumber: Data diolah. Semua hasil t-test tidak ada yang signifikan. Survivorship bias terjadi pada perhitungan diatas.

Pada panel A dengan benchmark IHSG dan return dihitung secara equally-weighted (EW), kinerja jangka panjang IPO setelah 1, 2 dan 3 tahun mengalami underperformance sebesar CAR 10,40\% (t-stat $=-0,64$, tidak signifikan), CAR 8,74\% (t-stat $=-0,37$, tidak signifikan) dan CAR $10,72 \%$ (t-stat $=-0,36$, tidak signifikan). Kinerja jangka panjang IPO setelah satu tahun di atas tidak mendukung temuan Martani (2004) yang mengungkapkan bahwa kinerja jangka panjang IPO outperformed sebesar CAR 1,9\% pasca 1 tahun IPO (250 hari). Akan tetapi, untuk tahun kedua dan ketiga pasca IPO hasil penelitian ini mendukung temuan Martani yang mengungkapkan terjadinya underperformance sebesar $1,66 \%$ dan $11,05 \%$. Tampak ada perbedaan tingkat underperformance yang relatif kecil antara penelitian ini dengan temuan Martani pada tahun kedua pasca IPO yaitu sebesar $7,08 \%$ (8,74\% - 1,66\%). Sedangkan kinerja jangka panjang IPO setelah 3 tahun antara hasil penelitian ini dengan Martani berbeda sangat tipis $(-10,72 \%$ versus $-11,05 \%)$. Sampel penelitian Martani adalah 297 perusahaan yang melakukan IPO tahun 1989 - 2000 dan benchmark pasar yang digunakan ialah IHSG. Hasil penelitian di atas juga mendukung hasil penelitian Suherman dan Buchdadi (2011) yang menemukan kinerja 
setahun pasca IPO underperformed sebesar 13,51\%, akan tetapi dua tahun pasca IPO hasil penelitian ini tidak mendukung Suherman dan Buchdadi (2011) yang mengungkapkan adanya outperformance sebesar $4,82 \%$.

Ketika return dihitung dengan value-weighted ( $\mathrm{VW}$ ), kinerja jangka panjang IPO juga mengalami underperformance sebesar CAR 9,05\% (t-stat $=-0,60$, tidak signifikan) pada tahun pertama, CAR 7,90\% (t-stat $=-0,37$, tidak signifikan) pada tahun kedua, dan CAR 6,73\% (t-stat $=-0,24$, tidak signifikan) pada tahun ketiga setelah IPO. Tampak kinerja jangka panjang IPO selama 1, 2 dan 3 tahun berbeda tipis ketika diukur dengan EWCAR dan VWCAR (-10,40\% vs $-9,05 \%$; $-8,74 \%$ vs $-7,90 \%$; dan $-10,72 \%$ vs $-6,73 \%)$. Hasil di atas mendukung temuan Suherman dan Buchdadi (2011) yang mengungkapkan terjadinya underperformance sebesar $18,00 \%$ dan $25,97 \%$ setahun dan dua tahun pasca IPO.

Masih pada Tabel 3 panel A (IPO semua perusahaan), namun dengan benchmark LQ45, ketika kinerja jangka panjang IPO diukur EWCAR memperlihatkan underperformance sebesar 20,91\% (t-stat $=-1,19$, tidak signifikan) pada tahun pertama, $22,15 \%$ (t-stat $=-0,89$, tidak signifikan) pada tahun kedua, dan $24,96 \%$ (t-stat $=-0,78$, tidak signifikan) pada tahun ketiga. Selanjutnya, dengan memakai pengukuran VWCAR, kinerja jangka panjang IPO juga mengalami underperformance sebesar $10,53 \%$ (t-stat $=$ 0,64, tidak signifikan), 9,80\% (t-stat $=-0,42$, tidak signifikan), dan 9,21\% (t-stat $=-0,31$, tidak signifikan) pada tahun pertama, kedua dan ketiga.

Pada Tabel 3 panel B (IPO manufaktur), dengan benchmark IHSG, pengukuran kinerja jangka panjang IPO dengan EWCAR menunjukkan terjadinya underperformance pada tahun ke-1 sebesar 9,71\% (t-stat $=-0,46$, tidak signifikan) dan tahun ke-3 sebesar $10,36 \%$ (t-stat $=-0,27$, tidak signifikan). Hasil ini mendukung temuan Pujiharjanto (2003) yang mengatakan bahwa kinerja perusahaan manufaktur setelah satu tahun IPO mengalami underperformance sebesar EWCAR 9,78\% di BEJ. Tampak perbedaan yang sangat tipis antara temuan penelitian ini dengan Pujiharjanto (-9,71\% vs -9,78\%). Return pasar yang digunakan sebagai benchmark pada penelitian Pujiharjanto ialah return IHSG. Periode penelitiannya tahun 1992-1998. Sampel sebanyak 124 perusahaan manufaktur. Lebih jauh, berlainan dengan tahun pertama dan ketiga di atas, penelitian ini memperlihatkan bahwa kinerja jangka panjang IPO tahun kedua mengalami outperformance sebesar EWCAR 0,56\% ( $\mathrm{t}$-stat $=0,01$, tidak signifikan).

Dengan benchmark pasar IHSG namun return dihitung secara value-weighted, kinerja jangka panjang IPO manufaktur di tahun pertama, kedua dan ketiga mengalami underperfomance sebesar VWCAR 25,12\% (t-stat $=-1,29$, tidak signifikan), 20,77\% ( $\mathrm{t}-$ stat $=-0,75$, tidak signifikan), dan 33,64\% (t-stat $=-0,96$, tidak signifikan).

Masih Tabel 3 panel B, dengan benchmark LQ45 dan return adalah equallyweighted, kinerja jangka panjang IPO underperformed sebesar EWCAR 12,90\% (t-stat $=$ 0,61, tidak signifikan), 6,08\% (t-stat $=-0,20$, tidak signifikan), dan 17,64\% (t-stat $=-0,47$, tidak signifikan) pada tahun ke-1, ke-2 dan ke-3 berturut-turut. Selanjutnya, dengan valueweighted cumulative abnormal returns (VWCAR), kinerja jangka panjang IPO juga mengalami underperformance sebesar 25,20\% ( $\mathrm{t}$-stat $=-1,31$, tidak signifikan) pada tahun pertama, 20,87\% (t-stat $=-0,76$, tidak signifikan) pada tahun kedua, dan 32,85\% (t-stat $=$ 0,95 , tidak signifikan) pada tahun ketiga.

Panel C (IPO non privatisasi) Tabel 3 memperlihatkan bahwa kinerja jangka panjang mengalami underperformance sebesar EWCAR 13,53\% (t-stat $=\quad-0,80)$ pada tahun 
pertama, 13,03\% (t-stat $=-0,54)$ pada tahun kedua, dan 13,53\% (t-stat $=-0,44)$ pada tahun ketiga setelah disesuaikan dengan return IHSG. Dengan menggunakan metode pengukuran VWCAR, kinerja jangka panjang IPO juga memperlihatkan underperformance sebesar 15,54\% (t-stat $=-1,02), 24,49 \%(\mathrm{t}-\mathrm{stat}=-1,14)$, dan 32,45\% ( $\mathrm{t}$ stat $=-1,18)$ pada tahun pertama, kedua, dan ketiga berturut-turut.

Ketika LQ45 sebagai benchmark, kinerja jangka panjang IPO juga mengalami underperformance baik ketika menggunakan EWCAR maupun VWCAR. Dengan EWCAR kinerja jangka panjang underperformed sebesar 24,59\% ( $\mathrm{t}$-stat $=-1,36), 27,15 \%$ $(\mathrm{t}$-stat $=-1,06)$, dan 28,53\% (t-stat $=-0,87)$ pada tahun pertama, kedua dan ketiga secara berturut-turut. Sedangkan ketika memakai VWCAR, underperformed berturut-turut pada tahun pertama, kedua dan ketiga sebesar 17,17\% (t-stat $=-1,04), 26,79 \%$ (t-stat $=-1,15)$, dan 34,67\% (t-stat $=-1,16)$.

Terakhir pada panel D, kinerja jangka panjang IPO privatisasi mengalami outperformance baik ketika diukur dengan EWCAR maupun VWCAR. Ketika disesuaikan dengan return IHSG, IPO privatisasi mengalami outperformance sebesar EWCAR 31,54\% (t-stat $=1,65), 48,89 \%(\mathrm{t}$-stat $=1,80)$, dan 28,60\% (t-stat $=0,86)$ pada tahun pertama, kedua dan ketiga pasca IPO. Lebih jauh, ketika disesuaikan dengan return LQ45, outperformance sebesar EWCAR 28,54\% (t-stat = 1,55), 44,95\% (t-stat $=1,72)$, dan $24,55 \%$ ( $\mathrm{t}$-stat $=0,76$ ) pada tahun pertama, kedua dan ketiga.

Pengukuran kinerja jangka panjang IPO privatisasi dengan VWCAR juga mengungkapkan terjadinya outperformance. Ketika disesuaikan dengan IHSG, terjadi outperformance pada tahun ke-1, ke-2 dan ke-3 pasca IPO sebesar 15,48\% (t-stat $=0,93$ ), $34 \%(\mathrm{t}$-stat $=1,45)$, dan 49,78\% (t-stat $=1,74)$. Sedangkan ketika disesuaikan dengan LQ45 outperformance-nya sebesar 15,87\% (t-stat $=0,93), 34,83 \%(\mathrm{t}$-stat $=1,45)$, dan $49,51 \%$ (t-stat $=1,68)$.

Analisis Buy-and-Hold Abnormal Returns. Gomper dan Lerner (2003) berargumen bahwa metode pengukuran dengan menggunakan CAR menjadi tidak tepat ketika returns sangat volatil. Oleh karena itu, mereka menyarankan untuk menggunakan metode pengukuran buy-and-hold abnormal returns (BHARs). Pada bagian ini analisis kinerja jangka panjang IPO dikelompokkan kedalam empat panel yaitu panel A (semua IPO), panel B (IPO manufaktur), panel C (IPO non privatisasi), dan panel D (IPO privatisasi). Periode pengamatan kinerja jangka panjang IPO adalah 1, 2 dan 3 tahun.

Pada Tabel 4 panel A, ketika pengukuran menggunakan equally-weighted buy-andhold abnormal return (EWBHAR) kinerja jangka panjang IPO mengalami underperformance terhadap return IHSG pada tahun pertama sebesar 18,78\% (t-stat $=$ 2,50, signifikan pada level 5\%), tahun kedua sebesar 56,17\% (t-stat $=-6,80$, signifikan pada level 1\%) dan tahun ketiga sebesar $108,46 \%$ (t-stat $=-9,49$, signifikan pada level 1\%). Hasil ini mendukung temuan Suroso (2005) yang mengungkapkan bahwa kinerja jangka panjang IPO underperformed sebesar 18,95\% pada tahun pertama ketika disesuaikan dengan return IHSG. Tampak perbedaan yang sangat tipis antara hasil pada penelitian ini dibanding dengan temuan Suroso (-18,78\% vs $-18,95 \%)$. Periode penelitian Suroso adalah tahun 1992-2002 dengan jumlah sampel IPO 216. Juga, temuan penelitian ini juga menyokong temuan Martani (2004) yang mengatakan bahwa terjadi underperformance pada tahun pertama, kedua dan ketiga sebesar 0,07\%, 9,15\% dan 17,58\% (return disesuaikan dengan return IHSG). Dibandingkan dengan temuan Martani 
tersebut, kinerja jangka panjang IPO pada penelitian ini jauh lebih underperformance pada tahun pertama, kedua dan ketiga berturut-turut $(-18,78 \%$ vs $-0,07 \% ;-56,17 \%$ vs $-9,15 \%$; dan $-108,46 \%$ vs $-17,58 \%)$. Sampel penelitian Martani adalah 297 perusahaan yang melakukan IPO tahun 1989 - 2000. Hasil penelitian ini juga mendukung temuan Suherman dan Buchdadi (2011) yang menemukan underperformance sebesar 25,68\% dan $75,63 \%$ satu dan dua tahun pasca IPO. Sampel penelitian Suherman dan Buchdadi adalah 37 perusahaan yang melakukan IPO periode Juli 2001-2005.

Ketika pengukuran menggunakan EWBHAR yang disesuaikan dengan return LQ45, kinerja jangka panjang IPO juga mengalami underperformance pada tahun pertama, kedua dan ketiga sebesar 20,43\% (t-stat $=-2,69$, signifikan pada tingkat $1 \%), 59,83 \%(\mathrm{t}-\mathrm{stat}=-$ 7,11 , signifikan pada tingkat $1 \%$ ), dan $114,34 \% \quad$ (t-stat $=-9,80$, signifikan pada tingkat $1 \%$ ). Ketika pengukuran kinerja jangka panjang menggunakan VWBHAR dengan benchmark IHSG, ditemukan bahwa pada tahun pertama dan kedua kinerja jangka panjang IPO mengalami underperformance sebesar 7,64\% (t-stat $=-1,01$, tidak signifikan), dan $15,87 \%$ ( $\mathrm{t}$-stat $=-1,92$, signifikan pada tingkat $10 \%$ ). Akan tetapi, outperformance terjadi ketika periode pengamatan kinerja jangka panjang IPO adalah 3 tahun yaitu sebesar $25,57 \%$ (t-stat $=2,23$, signifikan pada tingkat 5\%). Hasil di atas mendukung Suherman dan Buchdadi (2011) yang mengungkapkan adanya underperformance sebesar 0,62\% dan $0,53 \%$ setahun dan dua tahun pasca IPO.

Lebih jauh, dengan value weigthed returns dan benchmark LQ45, Tabel 4 panel A menunjukkan kinerja jangka panjang IPO juga mengalami underperformance sebesar $8,12 \%$ (t-stat $=-1,07$, tidak signifikan) pada tahun pertama, dan $15,57 \%$ (t-stat $=-1,85$, signifikan pada tingkat $10 \%$ ) pada tahun kedua. Akan tetapi, outperformance terjadi ketika periode pengamatan kinerja jangka panjang IPO adalah 3 tahun yaitu sebesar 23,93\% (tstat $=2,05$, signifikan pada tingkat 5\%) ketika disesuaikan dengan return LQ45.

Pada Tabel 4 panel B, tampak kinerja jangka panjang IPO mengalami underperformance ketika diukur dengan EWBHAR. Ketika disesuaikan dengan return IHSG, underperformance terjadi sebesar $19,06 \%$ ( $\mathrm{t}$-stat $=-1,95$, signifikan pada tingkat $10 \%$ ) pada tahun pertama, $58,47 \%$ (t-stat $=-5,77$, signifikan pada tingkat $1 \%$ ) pada tahun kedua, dan $116,11 \%$ (t-stat $=-8,67$, signifikan pada tingkat $1 \%$ ) pada tahun ketiga. Temuan kinerja tahun pertama tersebut mendukung temuan Suroso (2005) yang mengungkapkan terjadinya underperformance sebesar rata-rata $17,68 \%$ pada perusahaan manufaktur selama periode 1992-2002.

Sedangkan ketika disesuaikan dengan return LQ45, kinerja jangka panjang IPO underperformed sebesar $21,47 \%$ ( $\mathrm{t}$-stat $=-2,16$, signifikan pada tingkat $5 \%$ ) pada tahun pertama, 63,86\% (t-stat $=-6,17 \%$, signifikan pada tingkat $1 \%$ ) pada tahun kedua, dan $123,73 \%$ (t-stat $=-8,98$, signifikan pada tingkat $1 \%$ ) pada tahun ketiga.

Ketika diukur dengan VWBHAR, kinerja jangka panjang IPO mengalami underperformance pada tahun pertama dan kedua, tetapi mengalami outperformance pada tahun ketiga. Ketika kinerja jangka panjang IPO disesuaikan dengan IHSG, terjadi underperformance sebesar $23,20 \%$ ( $\mathrm{t}$-stat $=-2,37$, signifikan pada tingkat $5 \%$ ) pada tahun pertama, dan 29,68\% (t-stat $=-2,93$, signifikan pada tingkat $1 \%$ ) pada tahun kedua. Ketika disesuaikan dengan LQ45, kinerja jangka panjang IPO underperformed sebesar 24,53\% (tstat $=-2,47$, signifikan pada tingkat $5 \%)$ pada tahun pertama, dan 29,23\% (t-stat $=-2,82$, signifikan pada tingkat $1 \%$ ) pada tahun kedua. 
Tabel 4. Kinerja Jangka Panjang IPO Diukur dengan Buy-and-Hold Abnornal Returns (BHARs)

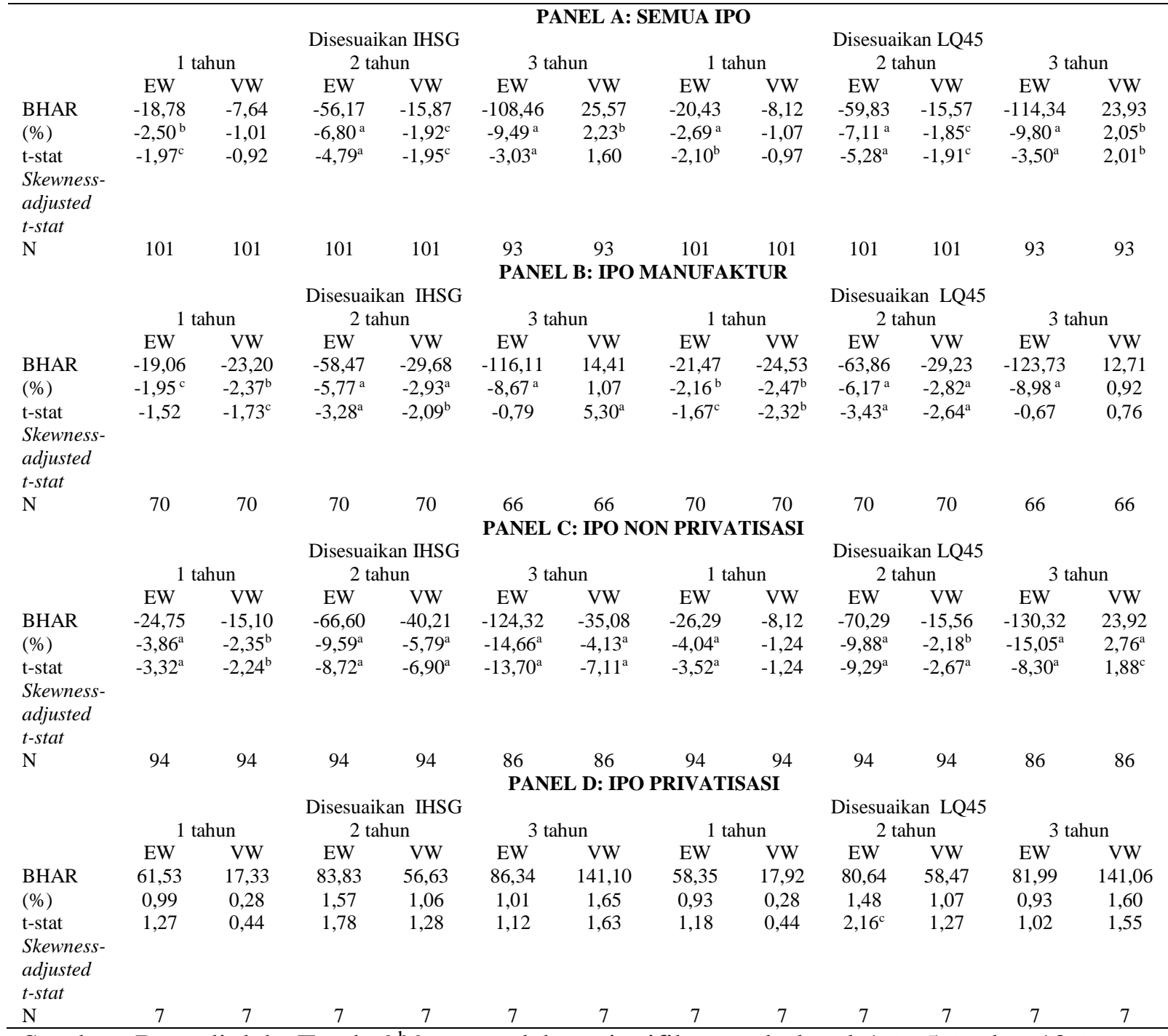

Sumber: Data diolah. Tanda a,b,c menandakan signifikan pada level 1\%, 5\%, dan $10 \%$. $\mathrm{n}$ ialah jumlah perusahaan dalam portofolio. Survivorship bias terjadi pada perhitungan diatas.

Namun demikian, pada tahun ketiga, kinerja jangka panjang IPO mengalami outperformance sebesar $14,41 \%$ (t-stat $=1,07$, tidak signifikan) setelah disesuaikan dengan return IHSG, dan sebesar $12,71 \%$ (t-stat $=0,92$, tidak signifikan) ketika disesuaikan dengan return LQ45.

Pada panel C (IPO non privatisasi), kinerja jangka panjang IPO mengalami underperformance baik saat diukur dengan EWBHAR maupun VWBHAR. Dengan benchmark IHSG, pengukuran menggunakan EWBHAR menghasilkan underperformance sebesar 25,75\% (t-stat $=-3,86$, signifikan pada tingkat $1 \%), 66,60 \%(\mathrm{t}$-stat $=-9,59$, signifikan pada tingkat $1 \%)$, dan $124,32 \%$ (t-stat $=-14,66$, signifikan pada tingkat $1 \%$ ) pada tahun ke-1, ke-2 dan ke-3 berturut-turut. Hasil tersebut mendukung temuan 
Manurung dan Soepriyono (2006) yang mengungkapkan terjadinya underperformance sebesar 8,27\%, 26,60\%, dan 47,42\% pada tahun pertama, kedua dan ketiga untuk 68 IPO perusahaan non privatisasi tahun 2000-2002. Ketika kinerja diukur dengan VWBHAR dan benchmark-nya IHSG, underperformance terjadi sebesar 15,10\% (t-stat $=-2,35$, signifikan pada tingkat $5 \%$ ) pada tahun pertama, $40,21 \%$ (t-stat $=-5,79$, signifikan pada tingkat $1 \%$ ) pada tahun kedua, dan 35,08\% (t-stat $=-4,13$, signifikan pada tingkat $1 \%$ ) pada tahun ketiga setelah IPO.

Dengan benchmark LQ45, kinerja jangka panjang IPO juga mengalami underperformance ketika diukur dengan EWBHAR dan VWBHAR. Besarnya kinerja jangka panjang tersebut adalah EWBHAR $-26,29 \%$ (t-stat $=-4,04$, signifikan pada tingkat $1 \%),-70,29 \%(\mathrm{t}-\mathrm{stat}=-9,88$, signifikan pada tingkat $1 \%)$, dan $-130,32 \%(\mathrm{t}-\mathrm{stat}=-15,05 \%$, pada signifikan pada $1 \%$ ) pada tahun pertama, kedua dan ketiga berturut-turut. Sedangkan dengan VWBHAR, underperfomance sebesar 8,12\% ( $\mathrm{t}$-stat $=-1,24$, tidak signifikan), $15,56 \%$ (t-stat $=-2,18$, signifikan pada tingkat 5\%), dan 23,92\% (t-stat $=-2,76$, signifikan pada tingkat $1 \%$ ) berturut-turut untuk tahun pertama, kedua dan ketiga.

Panel D menunjukkan bahwa kinerja jangka panjang IPO privatisasi outperformed tidak signifikan baik ketika menggunakan EWBHAR maupun VWBHAR. Dengan EWBHAR dan disesuaikan dengan IHSG, kinerja jangka panjang outperformed sebesar $61,53 \%$ (t-stat $=0,99$, tidak signifikan) pada tahun pertama, 83,83\% (t-stat $=1,57$, tidak signifikan) pada tahun kedua, dan $86,34 \%$ (t-stat $=1,01$, tidak signifikan) pada tahun ketiga. Hasil tersebut bertentangan dengan Manurung dan Soepriyono (2006) yang menemukan underperformance pada IPO privatisasi di tahun pertama sebesar 4,67\%, tahun kedua sebesar 8,94\%, dan tahun ketiga sebesar 63,31\%. Dengan VWBHAR dan disesuaikan dengan IHSG, kinerja jangka panjang IPO mengalami outperformance sebesar $17,33 \%$ (t-stat=0,28, tidak signifikan) pada tahun pertama, 56,63\% (t-stat=1,06, tidak signifikan) pada tahun kedua, dan $141,10 \%$ (t-stat=1,65, tidak signifikan) pada tahun ketiga.

Hasil penelitian di atas mendukung temuan Ahmad-Zaluki et. al (2007) yang menemukan kinerja 17 IPO privatisasi di Malaysia setelah tiga tahun mengalami outperformance sebesar BHAR 13,26\%. Lebih jauh, bukti empiris menunjukkan bahwa kinerja jangka panjang IPO privatisasi di banyak negara mengalami outperformance (Megginson dan Netter, 2001). Aussenegg (2000) mengatakan bahwa kinerja perusahaan privatisasi outperformed karena pemerintah ingin membangun reputasi melalui programprogram privatisasi dengan menciptakan lingkungan ekonomi berorientasi pasar (marketoriented economic environment). Ini akan mendukung aktivitas-aktivitas restrukturisasi dari perusahaan-perusahaan yang baru diprivatisasi dan selanjutnya mempunyai efek positif pada kinerja jangka panjang saham IPO privatisasi.

Dengan benchmark LQ45, terjadi outperformance sebesar EWBHAR 58,35\% (t-stat $=0,93$, tidak signifikan), 80,64\% (t-stat $=1,48$, tidak signifikan), dan 81,99\% (t-stat $=$ 0,93, tidak signifikan) setelah 1, 2 dan 3 tahun perusahaan melakukan IPO. Sementara itu, pengukuran dengan VWBHAR menghasilkan outperformance sebesar 17,92\% (t-stat = 0,28 , tidak signifikan) di tahun pertama, $58,47 \%$ ( $\mathrm{t}$-stat $=1,07$, tidak signifikan) di tahun kedua, dan $141,06 \%$ (t-stat $=1,60$, tidak signifikan) di tahun ketiga.

Selain menggunakan t-statistik konvensional di atas, penelitian ini juga menggunakan bootstrapped-skewness-adjusted t-statistics. Pada panel A, hasilnya adalah tingkat signifikansi EWBHAR 1 tahun yang disesuaikan dengan IHSG berkurang menjadi 
10\%, tingkat signifikansi EWBHAR 1 tahun yang disesuaikan dengan LQ45 berkurang menjadi 5\%, dan VWBHAR 3 tahun yang disesuaikan dengan IHSG menjadi tidak signifikan.

Pada panel B, hasilnya adalah tingkat signifikansi EWBHAR 1 tahun yang disesuaikan dengan IHSG menjadi tidak signifikan, tingkat signifikansi VWBHAR 1 tahun yang disesuaikan dengan IHSG berkurang menjadi 10\%, tingkat signifikansi VWBHAR 2 tahun yang disesuaikan dengan IHSG berkurang menjadi 5\%, EWBHAR 3 tahun yang disesuaikan dengan IHSG menjadi tidak signifikan, VWBHAR 3 tahun yang disesuaikan dengan IHSG menjadi signifikan pada tingkat $1 \%$, tingkat signifikansi EWBHAR 1 tahun yang disesuaikan dengan LQ45 berkurang menjadi 10\%, dan EWBHAR 3 tahun yang disesuaikan dengan LQ45 menjadi tidak signifikan.

Pada panel $\mathrm{C}$, hasilnya adalah tingkat signifikansi VWBHAR 2 tahun yang disesuaikan dengan LQ45 bertambah menjadi 1\%, dan tingkat signifikansi VWBHAR 3 tahun yang disesuaikan dengan LQ45 berkurang menjadi 10\%.Terakhir pada panel D, menggunakan bootstrapped-skewness-adjusted t-statistics kinerja jangka panjang tidak signifikan (sama dengan ketika menggunakan t-statistik konvensional), kecuali EWBHAR 2 tahun yang disesuaikan dengan LQ45 menjadi signifikan pada tingkat $10 \%$.

Membandingkan kinerja jangka panjang ketika diukur dengan CAR dan BHAR (pada semua panel; A, B, C dan D), terungkap bahwa metode pengukuran BHAR menyebabkan kinerja jangka panjang menjadi lebih underperformed ataupun outperformed. Hasil tersebut mendukung Fama (1998), Mitchell dan Stafford (2000) dan Gompers dan Lerner (2003) yang menyatakan bahwa metode BHAR dapat membuat underperformance maupun outperformance menjadi lebih besar (can magnify under/outperformance).

Analisis Fama-French Three Factor Model. Fama (1998) menyarankan untuk menggunakan Fama-French Three Factor Model (calendar-time approach) untuk menghitung kinerja jangka panjang dengan alasan; 1)perhitungan FFTFM memasukkan adanya hubungan antar observasi (allow the correlation between the firms in the sample to be taken in consideration), dan 2)FFTFM menggunakan inferensi statistik yang lebih baik (allow better statistical inferences).

Tabel 5. Kinerja Tiga Tahun Pasca IPO diukur dengan Fama-French Three Factor Model

\begin{tabular}{lcc}
\hline & Panel A (Semua IPO) & Panel B (IPO Manufaktur) \\
\hline$a_{p}$ & Equally-Weighted & Equally-Weighted \\
& 0,002 & 0,0001 \\
$\beta_{p}$ & $(0,455)$ & $(0,0266)$ \\
\hline$s_{p}$ & $-0,097$ & 0,347 \\
& $(-0,404)$ & $(1,047)$ \\
\hline$h_{p}$ & $0,447^{\mathrm{a}}$ & $0,413^{\mathrm{a}}$ \\
& $(10,292)$ & $(8,135)$ \\
\hline $\mathrm{R}^{2}$ & $0,249^{\mathrm{a}}$ & $0,214^{\mathrm{a}}$ \\
$\mathrm{F}$ & $(10,191)$ & $(6,645)$ \\
\hline $\mathrm{N}$ & $82,9 \%$ & $73,8 \%$ \\
\hline
\end{tabular}

Sumber: Data diolah. 
Pada bagian ini, peneliti hanya menggunakan equally-weighted returns, return IHSG, dan kinerja tahun ketiga saja. Hasil regresi FFTFM (lihat Tabel 5) mengungkapkan bahwa kinerja semua IPO (panel A) mengalami outperformance sebesar 0,2\% per bulan atau 7,2\% pada tahun ketiga pasca IPO (t-stat $=0,455$, tidak signifikan). Pada IPO manufaktur (panel B), kinerja juga outperformed sebesar $0,01 \%$ per bulan atau $0,36 \%$ pada tahun ketiga (t-stat $=0,0266$, tidak signifikan). Hasil tersebut berlawanan dengan hasil EWCAR dan EWBHAR (lihat Tabel 4 dan Tabel 5). Kinerja tiga tahun pasca IPO untuk panel A, dan B ketika diukur dengan EWCAR dengan benchmark IHSG adalah underperformance sebesar $10,72 \%$ (panel $\mathrm{A}$, $\mathrm{t}$-stat $=-0,36$, tidak signifikan), dan underperformance sebesar $10,36 \%$ (panel $\mathrm{B}$, $\mathrm{t}$-stat $=-0,27$, tidak signifikan). Ketika EWBHAR dengan benchmark IHSG digunakan untuk mengukur kinerja tiga tahun diketahui terjadi underperformance sebesar 108,46\% (panel A, t-stat $=-9,49$, signifikan pada $\alpha=1 \%$ ), dan underperformance sebesar $116,11 \%$ (panel $B$, t-stat $=-8,67$, signifikan pada $\alpha=1 \%$ ).

\section{PENUTUP}

Simpulan. Penelitian ini tidak mendukung hasil penelitian terdahulu di Indonesia yang mengatakan bahwa kinerja jangka panjang IPO mengalami underperformance. Penelitian ini menunjukkan bahwa umumnya kinerja jangka panjang IPO signifikan underperformed ketika pengukuran menggunakan metode BHAR. Akan tetapi ketika menggunakan metode CAR dan FFTFM, umumnya kinerja jangka panjang IPO tidak signifikan underperformed / outperformed. Dengan demikian, kinerja jangka panjang IPO tergantung pada metode pengukuran yang digunakan sebagaimana yang dikemukakan oleh Barber dan Lyon (1997), Brav dan Gompers (1997), Kothari dan Warner (1997), Fama (1998), Lyon et al. (1999), Brav et al. (2000), Loughran dan Ritter (2000), Eckbo et al. (2000), Mitchell dan Stafford (2000), Gompers dan Lerner (2003), Ang et al. (2005), dan Ahmad-Zaluki et al. (2007).

Saran. Berikut ini beberapa saran untuk penelitian selanjutnya: (1) Benchmark yang dipakai pada penelitian ini adalah market benchmark, yaitu IHSG dan LQ45. Menggunakan return pasar tersebut sebagai benchmark adalah bias karena ukuran (kapitalisasi pasar) IHSG dan LQ45 tersebut tidak sesuai (jauh lebih besar) dibandingkan dengan ukuran (kapitalisasi pasar) perusahaan yang melakukan IPO pada penelitian ini. Disarankan untuk menggunakan matching-company sebagai benchmark. Matchingcompany benchmark bisa didasarkan atas ukuran (kapitalisasi pasar) dan/atau book-tomarket value yang sama antara perusahaan yang melakukan IPO (sampel penelitian) dengan perusahaan non-IPO; (2) Penggunaan the bootstrapped skewness-adjusted tstatistic dalam menguji BHARs memiliki kelemahan yaitu tidak mempertimbangkan adanya serial correlation pada observasi BHARs. Untuk itu Jegadeesh and Karceski (2009) menyarankan untuk menggunakan the heteroskedasticity and serial correlation consistent t-statistics; (3) Walaupun penggunaan calendar-time approach yang paling banyak digunakan adalah Fama-French Three Factor Model, perlu juga dipertimbangkan penggunaan calendar-time approach lainnya seperti Carhart's F our F actors (1997) dan Pastor and Stambaugh's 5 F actors (2003) untuk mengukur kinerja jangka panjang IPO. 


\section{DAFTAR RUJUKAN}

Adler Manurung dan G. Soepriyono. (2006) "Hubungan Antara Imbal Hasil IPO dan Faktor-Faktor yang Mempengaruhi Kinerja IPO di BEJ", Usahawan, No.3, th. XXXV, Maret, hal.14-26.

Aggarwal, R., R. Leal, dan F. Hernandez. (1993) "The Aftermarket Performance of Initial Public Offerings in Latin America", Financial Management, 22, pp.42-53.

Ahmad-Zaluki, N., K. Campbell, dan A. Goodacre. (2007) "The Long Run Share Price Performance of Malaysian Initial Public Offerings (IPOs)", Journal of Business Finance \& Accounting, vol. 34., Iss.1-2, pp. 78-110.

Ang, A., L. Gu, dan Y. Hochberg. (2005) "Is IPO Underperformance a Peso Problem?", Working Paper, National Bureau of Economic Research (NBER)

Aussenegg, W. (2000) "Privatization Versus Private Sector Initial Public Offerings in Poland", Multinational Finance Journal, vol.4, no.1\&2, pp.69-99

Barber, B.M., dan J.D. Lyon. (1997) "Detecting Long-Run Abnormal Stock Returns: The Empirical Power and Specification of Test Statistics", Journal of Financial Economics, vol. 43, no. 3, pp. 341-372.

Brav, A. (1999) "Inference in Long-Horizon Event Studies: A Parametric Bootstrap Approach with Application to Initial Public Offerings", Journal of Finance, 54.

Brav, A., dan P.A. Gompers. (1997) "Myth or Reality? The Long-Run Underperformance of Initial Public Offerings: Evidence from Venture and Non-Venture Capital-Backed Companies", Journal of Finance, vol.56, pp.1791-1821.

Brav, A., C. Geczy, dan P.A. Gompers. (2000) "Is the Abnormal Return Following Equity Issuances Anomalous?”, Journal of Financial Economics, vol.56, pp.209-249.

C. A. Pujiharjanto. (2003) "Underpricing Pada Penawaran Umum Perdana di Bursa Efek Jakarta: Studi Empiris Emiten yang Listing Periode 1992-1998", Disertasi, Universitas Padjadjaran, tidak publis.

Conrad, J., dan G. Kaul. (1993) "Long-Term Market Overreaction or Biases in Computed Returns?", Journal of Finance, 48, pp.39-63.

Corhay, A., S. Teo, dan A. Tourani-Rad. (2002) "The Long Run Performance of Malaysian Initial Public Offerings (IPO): Value and Growth Effects", Managerial Finance, vol.28, pp.52-65.

Dawson, S.M. (1987) "Secondary Stock Market Performance of Initial Public Offers, Hong Kong, Singapore, and Malaysia: 1978-1984”, Journal of Business Finance and Accounting, vol.40, pp.65-162.

Dwi Martani. (2004) "Pengaruh Manajemen Informasi dan Determinan Lain Terhadap Harga Saham, Initial Return, dan Kinerja Saham Jangka Panjang: Studi Empiris Perusahaan Go Public di BEJ", Disertasi, Program Pascasarjana Ilmu Manajemen, Universitas Indonesia, tidak publis.

Eckbo, B.E., R.W. Masulis, dan O. Norli. (2000). "Seasoned Public Offerings: Resolution of the 'New Issue Puzzle"', Journal of Financial Economics, vol.56, pp.251-291.

Espenlaub, S., A. Gregory, dan I. Tonks. (2000) "Re-Assessing the Long Term Underperformance of UK Initial Public Offerings", European Financial Management, 6, pp.319-342

Fama, E. F. (1998) "Market Efficiency, Long Term Return, and Behavioral Finance", Journal of Financial Economics, 49, pp.283-306. 
Fama, E. F. dan K. French. (1993). "Common Risk Factors in the Returns on Bonds and Stocks", Journal of Financial Economics, 33, pp.3-56.

Gompers, P.A., dan J. Lerner. (2003) "The Really Long Run Performance of Initial Public Offerings: The Pre-Nasdaq Evidence", Journal of Finance, vol.58, pp.1355-1392.

I. B. Hartanto, dan S.I. Ediningsih. (2004) "Kinerja harga saham setelah penawaran perdana (IPO) pada Bursa Efek Jakarta", Usahawan, no.8, th.xxxiii, agustus, hal.3643.

Jegadeesh, N., dan J. Karceski. (2009) "Long-run performance evaluation: correlation and heteroskedasticity-consistent tests", Journal of Empirical Finance, 16, 101-111.

Jelic, R., B. Saadouni, dan R. Briston. (2001) "Performance of Malaysian IPOs: Underwriters Reputation and Management Earnings Forecasts", Pacific-Basin Finance Journal, 9, pp.457-486

Kothari, S. dan J. Warner. (1997) "Measuring Long-Horizon Security Price Performance", Journal of Financial Economics, 43, pp.301-339.

Levis, M. (1993) "The Long Run Performance of Initial Public Offerings: the UK Experience 1980-1988", Financial Management, Spring.

Loughran, T. (1993) "NYSE vs NASDAQ Returns: Market Microstructure or the Poor Performance of Initial Public Offerings?”, Journal of Financial Economics, 33, pp. 241-260.

Loughran, T. dan J. Ritter. (1995) "The New Issue Puzzle”, Journal of Finance, vol.50, pp.23-51.

Loughran, T. dan J. Ritter. (2000) "Uniformly Least Powerful Test of Market Efficiency", Journal of Financial Economics, vol.55, pp.361-389.

Lyon, J. D., B.M. Barber. dan C. Tsai. (1999) "Improved Methods for Tests of Long-Run Abnormal Stock Returns", Journal of Finance, vol. 54, no. 1, 165-201.

Megginson, W.L., dan J.M. Netter. (2001) "From State to Market: A Survey of Empirical Studies on Privatization", Journal of Economic Literature. Vol.39, no.2, pp.279-319.

Mitchell, M.L., dan E. Stafford. (2000) "Managerial Decisions and Long-Term Stock Price Performance", Journal of Business, vol.73, pp.287-329.

Peter, Suren. (2015) "Explaining Short Run Performance of Initial Public Offerings in an Emerging Frontier Market: Case of Sri Lanka", International Journal of Economics, Business and Finance, vol. 3, no. 1, pp.1-13.

Ritter, J. R. (1991) "The Long Run Performance of Initial Public Offerings", Journal of Finance, vol.46, pp.3-27.

Servaes, H. dan R. Rajan. (1997) “Analyst Following of Initial Public Offerings”, Journal of Finance, 52, pp. 507-29.

Shah, A. (1995) "The Indian IPO Market: Empirical Facts", Working paper, Centre for Monitoring Indian Economy, Bombay, India.

Suherman, dan A.D. Buchdadi. (2011) "The Long-Run Performance of Initial Public Offerings (IPOs): Comparison Between Shari'ah and Non Shari'ah-Based Firms", International Research Journal of Finance and Economics, 61, pp.74-84.

Suroso. (2005) "Hubungan Kinerja Jangka Panjang Saham Pasca-IPO dengan Optimisme dan Divergensi Opini Investor serta Tindakan Oportunitis Emiten", Disertasi, Program Pascasarjana Ilmu Manajemen, Universitas Indonesia, tidak publis.

Vismara, S., Paleari, S., dan Ritter, J. (2012) "Europe's Second Markets for Small Companies", European Financial Management, vol.18, no.3, p.352-388. 
Wen, Y. F., dan Cao, M. H. (2013) "Short-Run and Long-Run Performance of IPOs: Evidence from Taiwan Stock Market", Journal of Finance and Accounting, vol. 1, no. 2, p.32-40. 